\title{
A student's right to freedom of education and a teacher's fiduciary obligation to support it: A reply to the commentaries
}

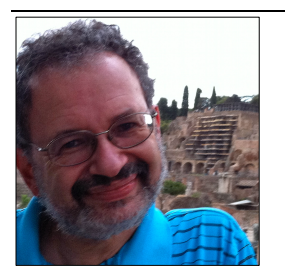

Eugene Matusov

University of Delaware, USA

\begin{abstract}
I feel honored to receive so many deep, critical, supportive, expanding, and thought-provoking commentaries on my original paper "A student's right to freedom of education" from undergraduate university students, educators, and educational researchers. These commentaries involve different genres: on-the-margin contextual comments, theoretical essays, ethnographies of their pedagogical practices, reflective sharing of good and bad personal educational experiences, personal authorial opinions, critiques, students' course evaluations, analysis of science-fiction literature, investigation of Bakhtin's biography, video replies, a list of questions, and so on. Once Socrates complained about the print text that it is impossible to ask the text new questions - the text won't reply to these questions. In this special essay, we tried to overcome this problem by involving each other in address-reply commentaries on each other's texts. We want to invite the readers of this special issue to join us in our dialogues of agreement and disagreement.

In my reply to the commentaries, I want to focus on the issues raised by the commentators that most touched me. This focus is on the relationship between a student's authorial education and a teacher's authorial teaching, where "teacher" is understood on a range between an individual educator and the entire society. I want to apologize in advance if I left out important concerns that some of the commentators wanted me to address (feel free to raise it again on the margin) of if I severely misinterpreted their idea or point (please correct me on the margin).

Here I focused on the following six major issues raised by the commentators. The first issue is raised by several undergraduate students from Canada, Russia, and South Korea about the possibility (and reality) of some students actively rejecting their freedom of education. Isn't it a case for rejection of my call for a student's right to freedom of education? The second issue raised by many commentators is about imaginary and real cases when foisted education is effective and even, arguably, more effective than student-owned education. Do these cases defeat my overall argument that student's freedom of education is required by education itself? The third issue was introduced by my colleague and a proponent of self-directed learning Kevin Currie-Knight when he asked a deceptively simple question of what I mean by "student." Usually, the role of a student is defined either by the institution or by the teacher, which implicitly goes against the spirit of my claim for a student's right to freedom of education. The fourth issue eloquently raised by an Ecuadorian undergraduate exchange student, Juan Francisco Poveda, studying at the Kyung Hee University in Seoul, about whether education must be subordinated to the needs of the society. Fifth, I consider the relationship between the education-for-myself and the education-for-the-other, the new terms introduced by my Russian colleagues. My overall vista in considering this relationship is authorship: the student's educational authorship or the teacher's pedagogical authorship. In a disagreement with some commentators and in an agreement with some other commentators, I argue that the teacher's pedagogical authorship must be subordinated to the student's educational authorship through the teacher's pedagogical fiduciary obligation. Finally, I will revisit the Kantian educational paternalism by considering the two, arguably, most powerful and extreme cases for foisted education: foisted education for the survival of the society and foisted education for a student's agency awakening. In my
\end{abstract}


conclusion, I will summarize the presented reasons for why a student's freedom is needed for education and briefly discuss how to test my claims.

Eugene Matusov is a Professor of Education at the University of Delaware. He studied developmental psychology with Soviet researchers working in the Vygotskian paradigm and worked as a schoolteacher before immigrating to the United States. He uses sociocultural and Bakhtinian dialogic approaches to education. His recent books are: Matusov, E. (2017). Nikolai N. Konstantinov's authorial math pedagogy for people with wings, Matusov, E. \& Brobst, J. (2013). Radical experiment in dialogic pedagogy in higher education and its Centauric failure: Chronotopic analysis, and Matusov, E. (2009). Journey into dialogic pedagogy.

\section{Acknowledgements}

I am thankful to Ana Marjanovic-Shane, Bryan Campbell, Xu Wang, and Shakhnoza Kayumova for their feedback and discussion of a previous draft of this essay.

$\cos \cos 80$

\section{When students reject their freedom of education}

In at least three commentaries, undergraduate students reject their freedom of education. Thus, in Shelley Price-Jones' commentary essay, her Russian undergraduate student in a South Korean university Alina Nedykhalova stated,

...I don't think that freedom in education is a good idea for Russian students. When I was in school, all my classmates didn't know what they wanted to do, and they didn't know what major they wanted to choose. Therefore, I agree with a statement that was mentioned in the article that it would be like "a blind leads the blind." I graduated from a school in Russia. When I entered Kyung University, I was in shock there because I have to choose what kind of class I want to explore. And this scared me because I don't want to make a big mistake and choose a wrong class or poor class.

In conclusion, I want to say that maybe not all students want freedom in education, what if some student wants a system like in a Russian University or in a Russian school.

Soo-Hyeon Park, a Korean student from the same university, brought the similar objection but directed it at students who might be too ignorant to know what is good for them,

We should consider the fact that children have different kinds of personalities and characteristics. Some might say that because everybody has different personalities, we should let them choose their own education curriculums. However, what about students who don't really want that freedom? There are indeed students who are independent, know what they like and enjoy the freedom. On the other hand, there are also students who don't actually know what they want to learn and want a curriculum that is already given out. Letting students have freedom of choosing their own subjects can rather cause confusion, especially at a young age.

Similarly, Mikayla Benner, an undergraduate student of Professor Jim Cresswell at the Ambrose University, Canada, wrote, 


\section{A student's right to freedom of education and a teacher's fiduciary obligation to support it}

Eugene Matusov

I do not believe education must be defined by the student, but neither do I believe that it must be defined by the state or by the teacher. I think that education is a system which is used for learning. There can be many forms of education. Not all students learn the same way and we should try to help students learn in a way that suits them best.

In my view, what unites two students - Alina and Mikayla (I am not so sure about Soo-Hyeon) - is that they articulate their desire for their own education. Alina does not seem to trust her own judgment about what classes and curricula to have for her education to be good. She wants her education to be fully controlled by her teachers and educational institutions. In my reading of her commentary, Mikayla wants her education to be designed somewhat collaboratively with her teachers and, probably, educational experts. I agree with Mikayla and Soo-Hyeon that students are different - even more, student may have different desires, interests, and constraints at a different time, with different curricula, with different teachers. I know many students of mine (but not all!) who agree with Mikayla and a few who agree with Alina. Yet, I argue that ironically, through their opinions about their education, both Alina and Mikayla have expressed their freedom of education. Let me explain.

When I argue for a student's right for freedom of education, I do not mean that each and every student must design their own education in the full scale as I listed in the section on unpacking this right, in my original article. Any freedom includes a possibility for delegation of some or all decisions to somebody else while the person reserves the right to change or revoke this delegation at any time. Alina exercises her freedom of education by saying (in my paraphrase), "Teachers and educational institutions, please design and control my education completely!" As far as Alina has the right to change her mind in general or in a particular case, it is fine from the perspective of freedom of education. The problem starts when Alina does not have this right or when she wants to impose her version of education on all "Russian students" (or on somebody else). The same is true for Mikayla. It is the expression of her freedom of education to demand collaboration with her teachers and educational experts. Alina's and Mikayla's freedom of education realizes itself when these students say, "I want this or that for my education." As far as the student's want rules their education, the student's right to freedom of education is affirmed. The problem starts when a student finds that they cannot change this arrangement, previously favored by them, or when the student tries to impose their preferred vision of education on other students.

Finally, I want to comment on why a student may distrust their own freedom of education. Of course, there can be many reasons for that: the peripheral nature of learning for the student, student being overwhelmed with other aspects of their life, the student's contextual and conditional trust in a particular teacher, and so on. However, one reason for that may be the student's past oppressive educational experiences. Under educational oppression, a student must unconditionally submit themselves to the authority's demands. In an oppressive institution, the student's most common (but not exclusive!) learning experiences is either to learn how to most successfully conform to the authority's unconditional demands "guess and please" the teachers' requirements (Rostotsky \& Polonsky, 1968) - or to actively or passively resist the authority. In both cases (but in different ways), the student's authorial agency in academic learning gets suppressed and/or remains unsupported (Matusov, 2011). In other words, Alina's rejection of her educational decision making might be a result of her long socialization in the Russian oppressive educational system: she might become "a good student," knowing how to get good grades, but a poor learner whose educational desires became suppressed by the conventional school. Oppressive educational systems often create a vicious cycle: it suppresses the educational authorial agency in a student while the student more and more distrusts their own underdeveloped and uninformed decision making and relies more and more on the authority to make these educational decisions for them. 


\section{A student's right to freedom of education and a teacher's fiduciary obligation to support it}

Eugene Matusov

\section{Can foisted education be effective?}

In their own ways, many commentators - namely, Raz Shpeizer, Amnon Glassner, Darren Dyck, James Cresswell, Mikayla Benner, David Kirshner, Belkacem TAIEB, Jeff King, Alina Nedykhalova, SooHyeon Park, and Kevin Currie-Knight (to a lesser degree) - challenge my argument that student's freedom is needed for a good education. I appreciate their challenge and critique, and I want to clarify and deepen my argumentation. Can foisted education be effective for a student's learning? Can a student make a poor educational decision about their education? Can an educator or an educational institution can make a better decision about a student's education than the student themselves? Can a student resist now but will appreciate foisted education in the future? My answer to all these questions is "yes." I know cases like that, and I appreciate some of the commentators bringing their own cases - real or imaginary. However, does this fact mean that students' education must be patronized, as Kant believed, and a student's right to freedom of education has to be abandoned? My answer is "no."

My major argument for a student's freedom of education is rooted in the authorial nature of education in whatever way to define it. A student authors their education. Education is a based on a student's authorial agency: the student's want, need, interest, challenge, puzzlement, curiosity, necessity, creativity, reflexivity, criticality, authorship of their actions and ideas, a transcendence of the given culture, self-actualization, mistake-making, goal setting, value defining, and so on. When the student's authorial agency is not legitimized, not supported, restrained, or oppressed, education gets withered to become learnification - learning without value and soul, using an educational philosopher Gert Biesta's term (2010, 2015). On a larger scale, a student's authorial agency of decision making about their education is more important than making a right educational choice. Let me consider a radical example, I mentioned in my paper, from the UK democratic school "Summerhill" about a boy, Freer, who chose not to learn reading and writing in school:

There was a boy at Summerhill who never went to a single class and who left the school scarcely knowing how to read or write.

Freer, Summerhill alumnus (apparently, in his 40s): I was one of the few pupils at Summerhill that

didn't attend lessons. I chose not to attend because I was not interested in it. I was very good at pottery carpentry those sort of things. I had a lot of confidence in my own ability to cope with the world through being able to do things with my hands. So, when I left Summerhill at the age of 15 , I could barely read or write, and I had no real idea what I was going to do or what I wanted to do.

On leaving Summerhill free, he spent five years hitchhiking around the world twice, after stay in Europe, he sold jeans in Turkey, his blood in Kuwait, worked in a kibbutz in Israel, was a film extra in India, worked in the mines in Australia, happened across the Carnival in Rio, gave conferences on Summerhill in California, went to prison in Canada, and finally ended up taking part in humanitarian movements in Pakistan and in India. In short, he visited over 90 countries without ever living through a single winter.

Freer: Every time I crossed the border, I would have to fill out a rather large form that required my name and my address and my age and what language I spoke, what religion I was et cetera. And I learnt to do these forms, write these forms in such a way, in such bad handwriting. But nobody could actually... even if I had spelt it correctly, they wouldn't have been able to read it. And most customs officials because they were... [in] Arab countries [they] couldn't read Latin script anyway, it didn't make much difference. But that was my only real drawback [of not being able to read and write]. 


\section{A student's right to freedom of education and a teacher's fiduciary obligation to support it}

I had during this period taught myself how to read and write correctly. I suppose it first came home when I was in Japan and I got a job being an English conversation teacher to scientists from a soap factory. ... I was explaining what my family does, what my father does, and they couldn't understand what a caravan [was]. My father was a caravan manufacturer and so ... They asked me to spell it for them. And at that point, I really got fed up. I thought, "God, I can't really spell this very well and I'm not sure how I could spell it." So, that really made me think, made me decide that I would, you know, teach myself how to read and write. I found it quite embarrassing.

So, after that... it wouldn't... it took me about three months. I got a dictionary and I started to read books. And just, just I did it myself. And by the time I got back to the UK, I was quite, yeah, normal, I suppose.

Interviewer: How do you feel now about Neill [the Summerhill school founder and principal] letting you go with such minimal qualifications?

Freer: Yeah, I often puzzled about that, both to do with Neill and my father in fact. I don't think... I would... Well, I would be very worried if my own children grew up not reading and writing. So, I've often wondered [laughed] around about how they could have done that. I don't really understand it. But they, neither Neil nor my father, seemed to have much concern about it. So, I think maybe they just felt that I would do it eventually. I think Neil always said that I will learn eventually.

Freer now has a degree in economics and is an industrial consultant giving advice in many countries in the third world. $\mathrm{He}$ is also increasingly involved in the management of community-based projects in Britain.

Freer: I think it took me a lot of confidence. I think, to sum it all, it gave me a lot of strength to trust in my own judgment and trust my own feelings ${ }^{1}$.

Did boy Freer make an educational mistake of not learning how to read and write? Arguably, yes, because then (and now?), reading and writing were practices that have been highly required in his society. Was young adult Freer angry at A.S. Neill, the founder of Summerhill, and his father for letting him out of school without learning these important skills? Yes, he was. Was Freer, in his 40s, ambivalent now, at the time of the interview? Yes, he was - as he said he might not let his children repeat his own educational experience. However, would it be better for Freer to be foisted to learn reading and writing? The final words of Freer suggest, no. At Summerhill, boy Freer had learned to direct himself on how to study what was important, interesting, and needed for Freer at the moment. When, as young adult in Japan, he faced the necessity to learn how to read and write ${ }^{2}$, he did it swiftly, deeply, and efficiently. It might be true that if Freer was forced to learn reading and writing in school, he might have had less frustration as a young adult. But, also it might be true that Freer would not be where and who he became - a deep, self-responsible, passionate, and self-directed learner. Arguably, freedom of education made Freer a more creative, more passionate, more adjustable, more resourceful, more inquisitive, more thoughtful, more responsible, and more open for life person. In short, education is not about reifiable learning outcomes - it is about people.

Both a student and an educational expert might make mistakes about what is important to study for the student. Actually, with more and more accelerating pace of the changes in our society technological, institutional, social, political, relational, - these mistakes are becoming more and more vast and severe. Probably, the best solution to this educational problem is for the student to focus on studying what is needed, important, interesting, puzzling, and curiosity provoking curious to them for the student

\footnotetext{
${ }^{1}$ https://www.youtube.com/watch?v=058xTHGYzIY

2 With proliferation of the Internet, smartphones, and social media, the need for reading and writing might be stronger for children now than in the time Freer grew up, at least in the developed countries (Ana Marjanovic-Shane, personal communication, July $30^{\text {th }}$ 2020)
} 


\section{A student's right to freedom of education and a teacher's fiduciary obligation to support it}

here-and-now ${ }^{3}$, which is the only thing to be guaranteed to last in the future. The power of a student's freedom of education is NOT that the student will be more right in choosing their curricula important for their future than an educational expert. Rather, it is rooted in the student's learning on the student's terms and demand (Collins \& Halverson, 2009). This on-demand learning promotes the student's authorial agency, which is the best prep for the unknown future.

In addition, in contrast to other practices, education thrives on the students' mistakes. Students' mistakes create teaching-learning opportunities for the students and teachers. When a mistake is owned by a student, when the student makes it freely as the student's own wrong decision, rooted in the student's own desires, interests, needs, curiosities, challenges, and puzzlements, the owned mistake often provokes a self-initiated inquiry in the student. In contrast, when a mistake is not owned by the student but imposed on them by foisted education, the student often becomes interested mostly in how to please the authority through finding a pattern of their actions or discourse that satisfies the teacher. In my recent book (Matusov, 2020a), I described a second-grade girl working on her math homework at an afterschool program where I met her. Passing by, I noticed that in one of her math puzzles, she subtracted a number (48) from another number (57) but got a bigger result (78). When I attracted her attention to this "miraculous" result, the girl insisted that this was how the teacher taught them. She said that she would be punished by the teacher if she deviated from the teacher's math procedure. Although the girl might be wrong about what the teacher taught her, she was probably right that her math instruction was entirely focused on pleasing the teacher. It was clear for me that the girl was not interested in engaging herself in math but rather in pleasing her teacher and finishing her homework as fast as possible to go to play with other kids. To some degree, it would have been even worse when a student learns "correct" procedures through such soulless learning. As I wrote in the book,

For me, the issue is not that the teacher taught a wrong mathematical procedure (I hope not!) or did not guide the girl the math well (which probably was the case). What is very important for me in this example is that the girl treats the (school) math reality as an authoritative procedural ritual (McLaren, 1993), in which she engages, which excludes any possibility for her own judgment and understanding. The student learned to recognized patterns of manipulation with numbers to please the teacher (Matusov, 2020b). I argue that in this case, the teacher serves as a Holy Priest of Epistemological Divine Authority to whom the student offers her servitude to avoid punishment and, probably, even to reap up some rewards in the form of praise and good grades (Matusov, 2020a, pp. 37-38).

The problem with the Kantian educational paternalism, which promotes foisted education, where the teacher or other educational authority knows better what, whether, and how a student must study, is that it severely curbs, disables, postpones, or delegitimates the student's authorial agency, on which education is based (and must be based). The educational paternalism zombifies a student's learning, even when this learning is "effective" - predictably leading the student to the correct answer or action on the teacher's demand or on an exam.

\footnotetext{
${ }^{3}$ A student's here-and-now interest, need, or puzzlement is not an individualistic notion. From the fact that people have different herean-now interests does not mean that education can occur only in one-on-one tutoring or via autodidact. People induce here-and-now interests in each other. All the time, people create here-and-now moments in each other. For example, I have successfully created the here-and-now interest in many of my commentators and hopefully in some of my readers by writing these papers on a student's right to freedom of education. This shared here-and-now interest might have different intensity and meaning for the participants and can even be based on disagreements. In addition, for the sake of their participation in a critical dialogue with others, students may compromise on their here-and-now interests by joining topics that may not find fully or initially interesting. However, in some cases, a person's here-and-now educational interest might not be shared - the person becomes an autodidact student or wants one-on-one guidance.
} 


\section{A student's right to freedom of education and a teacher's fiduciary obligation to support it}

If paternalism is NOT the principle of education, can it still be legitimate in education in some cases? My answer is yes. First of all, legitimate paternalism can provide safety in education. For example, a child may want to explore a poisonous mushroom by tasting it. A more knowledgeable person, the child's teacher or a parent or an older sibling, might prevent the child from this learning experience, which can be deadly for the student. In this case, paternalism, ensuring safety, is legitimate. Sometimes, safety (or something else) has to be prioritized over education. However, in this case, paternalism limits education rather than promotes it. It should be recognized that this safety is done at expense of education. Education, like any practice, has its limits, and paternalism may help to set this limit for the sake of safety (or something else).

Second, legitimate educational paternalism can be based on the student's trust in the teacher, who tells the student, "Trust me, you may be benefited from that." If the student grants the trust to the teacher, this paternalism is legitimate. If not, then not. This educational paternalism gains its legitimacy from the fact that it is conditionally consented by the student. The student has the right to give it, to withdraw it at any time, to require justification, and to negotiate it. The teacher's epistemological, pedagogical, and organizational authority is based on the student's constant evaluation of the usefulness, quality, and meaningfulness of the teacher's paternalism for the student. There is nothing wrong for Alina to demand full educational paternalism for her education when this paternalism remains consented by Alina. The same is true for Mikayla, demanding partial, collaborative, paternalism from her teachers. The student's consent - a version of freedom of education - and not paternalism is what constitutes education.

\section{What is a student?}

Along with Belkacem TAIB (see Appendix I in my original paper), in his thoughtful commentary, Kevin Currie-Knight asks me a deceptively simple but actually very profound question, "What is a student?" To challenge my argumentation, Kevin provides an interesting example of his infant-daughter with whom Kevin and his wife were playing while apparently violating her right of freedom of education (RoEF), "Regularly, we violate her RoEF by forcing her into 'tummy time;' we put her onto her stomach so that she can strengthen muscles necessary for crawling and gain necessary practice being on her stomach. Her forceful cries during this process tell us that this educational experience (we've tried in vain to explain to her that it is an 'opportunity') is entirely against her will. The question is whether she is a student in Matusov's relevant sense." Kevin goes on to claim that in this example, his infant daughter was a student who does not need to have freedom of education. Here I am not going to address the second part of Kevin's claim but rather focus on the first part: whether Kevin's daughter was a student and what makes a student. I think Kevin's question is fair and important to consider in the context of my paper. Spoiler alert: I do not think that Kevin's daughter in this example was a student - not in a spirit of my argument about a student's right to freedom of education.

I see two major problems with Kevin's argumentation. First, it seems to equate learning with education. Second, it equates education-fulness - i.e., having educational aspects, educational moments, or educational experiences - with education. Not any learning is education. Not any educational experience is education. For example, the phenomenon of learned helplessness - a person's learned belief that a task cannot be completed because it is beyond the person's control - doubtedly can be called education (or, at least, not always). But why? Learning of a new attitude is genuinely present in this phenomenon. How is it different from learning how to cope with adverse circumstances? The latter learning feels like a good candidate for education, while the former does not. In my view, it is because education involves something in addition to learning: namely, evaluation of this learning - whether it is good or not for the person. Good 


\section{A student's right to freedom of education and a teacher's fiduciary obligation to support it}

learning becomes education ${ }^{4}$, bad learning is not. Who makes this evaluation? In my view, it must be first and foremost "the student" - i.e., a person who learns. Of course, other people might disagree. A teenager, who learns how to binge drink, may call this learning education, while his mother may disagree. Education can be contested. Kevin wrote about his infant daughter, "Certainly, she is a learner." Maybe (although I doubt even about that), but she might not necessarily be having educational experience because I am not sure she got involved in the evaluation of her learning. I agree that she experienced learning, but I am not sure she experienced education. But there is another reason of why I doubt that Kevin's infant daughter was a student (or even a learner).

The second problem in Kevin's argumentation is to equate playfulness with play, artfulness with art, having learning moments with being a learner, education-fulness with education. Having aspects of play, art, learning, or education does not mean that the whole activity can be characterized as play, art, learning (as an activity), or education. As a sociocultural scholar Jean Lave convincingly argued, learning is ubiquitous, and it is an aspect of any activity (Lave, 1992, April). A disengaged student sitting at a math lesson in a conventional school might learn that math is boring, and that math is not for her. Or she might learn how to smuggle texting on her smartphone without getting in trouble. Or she might learn how to make good a good grade by successfully guessing what the teacher wanted from them and pleasing the teacher. Or she might indeed learn math. To live means to learn.

However, at some point, a person may want to assume a particular stance, a particular role, a particular position, a particular orientation by dedicating their activism to specifically to learning or even to good learning. "I want to learn Spanish." "I wonder if cutting my hairs make them grow faster." "I want to know why the sky is blue and not green, but the grass is green and not blue." "How can I change the wallpaper on my smartphone?" "Why can't a face mask prevent from a nasty smell, but can help against the Covid-19 virus?" "I want to learn to play this computer game." These questions and statements reflect big and small learning that the person assigns to themselves as special deliberate learning activities. This self-assigned good learning makes a person an educatee (or a learner).

Furthermore, an educatee becomes "a student" when the person's self-assigned learning is recognized by other people. Of course, my definition of "a student" is different from the conventional one. In the conventional definition, "a student" is a person whom the society or an institution assigns education - i.e., good learning from the society's point of view. Whether the person also co-assigns this foisted education to themselves is not very important from the conventional definition. In contrast, in my definition of student, other people recognize an educatee and their academic rights that I listed in my original paper.

So, in sum, why do I doubt Kevin's infant daughter is a student despite her obvious learning experiences? First, it is because I am not sure that she got involved in evaluation of her learning experiences. Second, I doubt that she assigned any good learning to herself in this example. Third, her parents apparently did not recognize her rights as a student.

Democratic schools like Jim Rietmulder's The Circle School (Rietmulder, 2019), or Dan Greenberg's Sudbury Valley School (Greenberg, 1991), or A.S. Neill's Summerhill (Neill, 1960) created the leisure environment for the children and youth. This leisure has several forms: plays, friendship hangouts, hobby activities, and, yes, education (Matusov, 2020a). In my view, education is only one of many leisure

\footnotetext{
${ }^{4}$ At the same time, I do not think that education is equated with good learning or can be reduced to good learning. Education is bigger than good learning. Education also involves good non-learning, like, for example, "becoming a different person," switching a paradigm - the personal discontinuity recognized by the person as good one (cf. epiphany, psychedelic trip, revelation, insight, keisaku -https://en.wikipedia.org/wiki/Keisaku, mediation, "shock therapy," paradigm shift). Discussion of non-learning education is beyond this paper.
} 


\section{A student's right to freedom of education and a teacher's fiduciary obligation to support it}

forms at democratic schools. Not every activity in those democratic schools is education: plays, friendship hangouts, hobby activities (e.g., "corporations" at The Circle School), assembly meetings for decision making, judicial committees. Although these activities might have learning and even educational aspects and moments. In this regard, I respectfully disagree with Jim R.'s comment on the margin of my original paper expanding education to play. I wrote in my paper: “...children prefer playing over voluntary attendance of classes (Greenberg, 1991; Neill, 1960; Rietmulder, 2019).” Jim R. commented on the margin of my original paper

Yes, but this is exactly children's choice to engage in intrinsic education (which is what you are addressing here), rather than the less effective and less valued foisted classes, which, by the way, are usually instrumental education. Chapter 7 of my book [(Rietmulder, 2019)] could be viewed as my assertion that 'deep play' is intrinsic education. Also, in the last decade I believe there is a renewed recognition of the educational value of children's play, among childhood scholars and education practitioners.

I think it is a dangerous and unfortunate trend to reduce play to education and to exploit play for education because it diminishes play as an existential human (leisurely) endeavor along with education and other important existential endeavors. At the same time, I think that purification of education as a form of leisure - banning all other forms of leisure to push forward education - is both undesirable and impossible for a truly educational environment. Different types of leisure feed on each other and create the ecology of "school" (in Ancient Greek's sense) where education can have more chances to occur and be supported. Also, the boundaries between education and other leisure and non-leisure activities are not always sharp and clear.

\section{Personal education and society}

Juan Francisco Poveda, an Ecuadorian exchange student from the Kyung Hee University in Seoul, asked me in his commentary,

...I consider that education per-se could not be very individually defined. I believe that part of the goals of education is to serve as a guide to live within a community. On this regard, I have seen that you strongly agree with the self-determination of education, mainly when you mention that Education is primarily the business of the student, not from the state, the public, the taxpayers or even not the business of teachers and schools. Wouldn't you consider that this extent of self-construction of the concept of education could affect the goal of constructing individuals able to live in a community?

I have two answers to Juan's profound question. As an educational pluralist, I think it is up to a student to answer this question and not up to me or any other educator. If a student wants to subordinate their personal education in service to the society (or any other cause, limited by the law and morality), the student has a full right to do so. However, the student also must have a right to change their mind about the purpose of their personal education at any point.

As an educational visionary, having a particular educational philosophy, I see the primary goal of personal education to be deconstructive, not constructive. A student should primarily critically examine the society rather to harmoniously socialize in it. The student should liberate themselves from their prior uncritical socialization in the society, from the colonization by their culture, by their language, by their community. Personal education, in a way I envision it, helps the student to critically evaluate cultural, social, political, economic values in which they have been uncritically socialized: which of the existing societal 


\section{A student's right to freedom of education and a teacher's fiduciary obligation to support it}

values to accept and which to reject and why and/or which of new values be must be add. In short, personal education that $\mathrm{I}$, as a particular educator, envision disrupts the society rather than harmonizes with it. It is not by chance that Socrates - the first articulator of the deconstructive personal education, to which I subscribe, - was sentenced to death by the democratic Athenian society for "corrupting the youth of Athens."

At the same time, society can legitimately set demands on people who want to join important societal practices. For example, to become a jet pilot, the society and/or business might want to set the required skills, knowledge, and attitudes for a job candidate. If a person wants to become a jet pilot, they might be forced to learn these skills, knowledge, and attitudes to be accepted for a job or get a pilot license. It is important to emphasize that these demands, impositions, and summative assessments of whether the person is qualified or not must be outside of education itself. There must be a firewall between these impositions and education. Educators must not participate in the imposition of the curriculum or in sorting their students based on their competencies and knowledge. Rather, educators must be fiduciaries of the student's desire to become a pilot (or any other practitioner) - see the next section where I expand this argument. Educators must help the student who desires to join certain practice, which society or businesses defined. When a student feels to be ready, society or businesses can legitimately check if the applicant for the practice is competent.

\section{The relationship between the authorial education-for-myself and the authorial education-for-the-other}

My Russian colleagues - Oleg Osovsky, Vera Kirzhaeva, Ekaterina Chernetsova, and Elizaveta Maslova - have introduced two very interesting and promising notions: "the education-for-myself" (loosely defined as self-study, autodidact) and "the education-for-the-other" (loosely defined as teaching). Here I want to discuss the authorial nature of education-for-myself and education-for-the-other and their relationship.

The authorial education-for-myself starts with a student's "wants" or "don't wants" with regard to their own education. For example, at a very basic level, Alina demonstrated her authorial education-formyself by wanting to submit herself to the authorities making decisions about her education. Similarly, Mikayla concurred with her professor Jim Cresswell's demand to ban the use of technology in their class. "I trust your pedagogical judgment. I like your demand," - are realizations of the student's authorial education-for-myself. Of course, the authorial education-for-myself is rather limited in both examples of either surrendering to the authority (Alina) or concurring with the teacher's demand (Mikayla).

However, a sophisticated authorial education-for-myself goes much beyond a student's desire to submit themselves to the authority or concur with the teacher. Professor Shelley Price-Jones' Korean undergraduate student HyunJung Kim analyzed a science fiction novelette "Fire Watch"5 by writer Connie Willis to reveal a much more elaborate and sophisticated case of the authorial education-for-myself. In the novelette, Hyun Jung describes, a historian, Mr. Bartholomew, sets himself on a time-traveling educational expedition to observer and experience the fire of St. Paul's Cathedral in London as a result of the night air raid of 29-30 December 1940 as a part of the Nazi-German bombing "blitzkrieg" campaign. When Mr. Bartholomew returns back to his time and attends a history exam about St. Paul's Cathedral fire, his professor Dunwoody asks very technical exam questions about the event like the number of bombs and casualties. Mr. Bartholomew "felt the anger inside and asked the professor. 'Isn't there any question about what happened to people?' answers Professor Dunwoody. 'Mr. Bartholomew, you're the one who answers

\footnotetext{
${ }^{5}$ See the story here: http://www.infinityplus.co.uk/stories/firewatch.htm
} 


\section{A student's right to freedom of education and a teacher's fiduciary obligation to support it}

the question, not the one asking questions'" (Kim in Price-Jones, p. xxx). Deep authorial education-formyself involves the student's own interest, curiosity, puzzlement, asking questions, addressing a difficulty, assigning themselves a learning activity, and/or sending themselves on a prolonged learning journey. The teacher's questions must be subordinated to the student's questions. The teacher's questions must aim at provoking the student's interests, puzzlements, inquiries, positions, questions, and the development and testing ideas - the student's own and alternative ideas.

The Russian colleagues analyzed Bakhtin's education-for-myself and education-for-the-other in their commentary. Young Bakhtin's education-for-myself occurred mostly through homeschooling and his autodidact education. In their commentary, they provided a lot of evidence for Bakhtin's interests, inquiries, and learning journey into philosophy (especially in Kantianism and neo-Kantianism), literary critique, philology, history, linguistics, ethics, diverse foreign languages, sociology, and literature. Bakhtin's authorial education-for-myself lasted all his life. Apparently, it did not include physics, math, chemistry, psychology, athletics, etc., although we should not be so sure because Bakhtin's notion of "chronotope" was borrowed from biology (and, maybe, physics) (Bakhtin, 1991, p. 84) ${ }^{6}$. Still, there was a strong vector of Bakhtin's educational authorship aiming at philosophy and philology. Authorial education-for-myself is always selective, if not overtime, then at the given moment.

Academic freedom ${ }^{7}$ of the authorial education-for-the-other - the right of a teacher to decide what and how to teach - is more recognized for university professors, who are assumed to be active scholars and researchers than for teachers per se. However, even for professors-scholars, this freedom is often limited by faculty committees. Interestingly enough, in their commentary, Oleg, Vera, Ekaterina, and Elizaveta report that Bakhtin had to fight for his and other teachers' right to teach sociology rather than a new Study of socialism" in the Soviet Union in the early 1920s. The notion of the authorial education-forthe-other is at odd with the modern prevailing fashions in education such as "the educational standards," "the common core," "evidence- and research-based teaching," etc. because in former, teaching is viewed as an art, while in the latter, teaching is viewed as a technology guided by the positivistic science (or by the official political ideology as it was in the USSR). I argue that a teacher has the academic right to define their own authorial teaching - what and how to teach - without an interference of the state, institutional administration, or their colleagues.

Academic freedom of the authorial education-for-myself - the right of a student to decide whether, what, and how to study - is not much recognized at all, in any society so far, beyond a few democratic schools and some homeschooling. In my original article in this special issue, I argue for this academic freedom to be recognized as defining education.

The further question emerges, which is what the relationship between the teacher's academic freedom and the student's academic freedom should be. Reading the commentaries, I abstracted at least three possible answers to this important question. First, Darren Dyck and James Cresswell seem to argue for the priority of the teacher's academic freedom over the student's academic freedom or maybe even overruling the student's academic freedom altogether. If a teacher feels that it is pedagogically prudent to impose the ban of technology in their classroom, the teacher has the right to do that. At least, this is how I read their commentary.

\footnotetext{
6 "In the summer of 1925, the author of these lines [30-year old Bakhtin] attended a lecture by A. A. Uxtomskij [a famous Soviet biologist] on the chronotope in biology; in the lecture questions aesthetics were also touched upon" (p. 84).

7 "...scholars should have freedom to teach or communicate ideas or facts (including those that are inconvenient to external political groups or to authorities) without being targeted for repression, job loss, or imprisonment" https://en.wikipedia.org/wiki/Academic freedom
} 


\section{A student's right to freedom of education and a teacher's fiduciary obligation to support it}

In contrast, while James Cresswell's student Mikayla Benner wholeheartedly agrees with the teacher's ban of technology, she argues for a more collaborative relationship between the teacher's academic freedom over the student's academic freedom, citing my pedagogical practice of Curriculum Map, where students can have a right to select a curricular topic for their next class listed on the Map. Mikayla envisions the equal power relations between the teacher and the student.

The third type of relationship depicted by Olga Shugurova. In my interpretation, she seems to want to subordinate the teacher's academic freedom to the student's academic freedom. If it is the case, I agree with her. I think the teacher's pedagogical authorship must serve the student's educational authorship. The teacher has a fiduciary obligation ${ }^{8}$ to the student.

There are two major pitfalls and challenges for the teacher's fiduciary obligation to the student's authorial education-for-myself: paternalism and slavishness. The teacher's paternalism, articulated by Kant, involves the teacher's belief that by being ignorant, the student is incapable of making good decisions about their own education, and, thus, they must be subjugated by force or manipulation to the pedagogical experts. I have already discussed this educational paternalism in my original paper and in previous and following sessions in this reply-essay.

The teacher's slavishness is a belief that the teacher must follow the student's will to the letter and try not to interfere with it in any way. In my observation, this pitfall is common among democratic and selfdirected learning educators. In my original paper, I quoted A.S. Neill, the founder of the UK democratic school Summerhill, who, in my view, came very close to the teacher's slavishness by saying that an educator "should never influence the choices children make" (see also Jim R.'s and my discussion of this quote on the margin - both of us disagreed with Neill). Some democratic educators try to stay away from any suggestions or exposures of new ideas or learning activities that might "impose" ideas or learning on their students. In their view, a student must explicitly ask them for it before such a democratic educator would share something new with them. In my perspective, even beyond obvious issues of safety, the slavish following the students' educational desire (or the explicit lack of them) is arguably a violation of the teacher's fiduciary obligation through negligence, using a legal term. Let me explain why.

The part of the social contract between the student and the teacher, the contract initiated by the student, is the student's demand for and trust in the pedagogical otherness of the teacher (cf. Jeff King's commentary). The student trusts that the teacher can provide an interesting provocation, interesting alternative idea, interesting learning activity, interesting inquiry, important information that can be unknown to the student, but sensitive for the student's educational needs and helpful for their educational authorship. But this "interesting" and "important" must be interesting and important for the student. The student's educational needs, interests, and authorship are not fully known by the student internally or by the teacher externally. Even more, all of them are dynamic and not static, constantly emerging, and transforming in the student. Even-even more, this dynamism, emergence, and transformation can be inspired by the student's educational authorship and by the teacher's pedagogical authorship. The teacher must help to something (i.e., the student's emerging authorship) that does not yet exist. It is a challenge for educators to support the diverse and changing educational desires of their students. That is why teaching is an art and not technology. The magic of the teacher's pedagogical fiduciary obligation is to be sensitive to something that is not yet there.

\footnotetext{
${ }^{8}$ Cf. the legal notion of "fiduciary obligation" of "fiduciary duty" here: https://www.investopedia.com/ask/answers/042915/what-aresome-examples-fiduciary-duty.asp
} 


\section{A student's right to freedom of education and a teacher's fiduciary obligation to support it}

Eugene Matusov

I do not believe that there is a formula for a good fiduciary obligation of the teacher to the student. It is always in flux; it is always ready to break and does break its boundary of the legitimacy, and, thus, it requires authorial judgments from the teacher and the student. Finally, it involves a negotiation of the boundaries of the legitimacy of what the teacher offers between the teacher and the student. This negotiation is never guaranteed to be successful. The negotiation's breakdown might lead to "no-fault divorce" between the student and the teacher when the student withdraws their educational interest, need, and trust in the teacher. In this case, the student becomes either autodidact or has to search for another teacher.

\section{The Kantian educational paternalism at its extremes: Revisited}

Here I want to consider two, probably, most extreme and strongest arguments for the Kantian educational paternalism. The first extreme argument for educational paternalism comes from what can be called "education for survival." According to this argument, education must be foisted in the name of survival for the student and/or the entire society. The second extreme argument comes from what can be called "education for awakening." Ironically, this argument comes in the name of the student's self-actualization. The student's consciousness has to be awakened by foisted education, so the student can engage in selfactualization. Let me consider each of them.

\section{Foisted education for survival}

I am thankful to my colleague and friend Bryan Campbell for the articulation of this argument as a part of his feedback on previous draft of this essay.

Bryan Campbell: Some educators justify foisted education as necessary for the safety of the student and/or the society. They claim that forcing students to learn about reading, writing, math, science, democracy, the country, etc., is about the personal safety of the student and the entire society. Ignorance kills - they may say - or at least, harms.

One can make the argument that one should learn and read and write for their own safety. One can extend that argument of safety into these other areas of education. One could extend it to an extreme like all of you need to learn biology and science and atmospheric things because of the crisis. We're facing is global warming and if all of us aren't equipped to deal with that crisis as it pops up. Then we will see the apocalypse. So, that's to me like pushing those arguments to an extreme. And I think to some extent that maybe that's the basis of the mandated, foisted education that if our students don't know all of these things, it will create an apocalyptic crisis. So, this idea of safety and an extreme form might be the underlying sentiment or even the explicit justification for that mandated education.

My rebuke to this argument is the following. Foisted education for survival is, probably, the ultimate defense of the Kantian educational paternalism and, arguably, one of the strongest counterarguments of my paradigm. Since the Enlightenment, education has been viewed as the universal solution for any societal problem. For example, the recent outcry about ubiquitous racism remaining in the American society is often responded by mandatory anti-racist training imposed on all members of many institutions and businesses, especially on White people since they are considered to be the root of the racism problem (e.g., see, for example, DiAngelo, 2018).

I think this is an abuse of education. It confuses education with advocacy (or propaganda, with its strongest sense). Advocacy is a social practice aiming at shaping people's subjectivities - the object of advocacy - into a particular mold, predefined by the advocacy designers. I do not want to dismiss advocacy. 


\section{A student's right to freedom of education and a teacher's fiduciary obligation to support it}

Advocacy can be a legitimate and useful social practice. Legitimate advocacy must be honest - factually true. It can take diverse forms like health warning labels on cigarettes, advertising (including political advertising), issue advocacy, political propaganda and agitation, and so on. Advocacy training and advocacy exams can be a legitimate entry point for some practices. For example, at The Circle School (TCS), a democratic private K-12 school near Harrisburg, Pennsylvania, safety and organizational training and exams are conditions for students and staff to join certain "corporations" that require such training and exams. If a student or staff member wants to join this corporation, they must pass the training and/or the exam, first (Rietmulder, 2019). What, in my view, makes advocacy legitimate, besides being honest, is that it treats its targeted people with dignity, expecting them to be the final agency for making decisions about their own life. One can be informed about the health hazards of smoking but still chooses to smoke. A TCS student may decide not to join the corporation or demand to change its rules. Illegitimate advocacy treats its targeted people as drones-in-making - any dissent is viewed as a crime, stupidity, and/or moral sin.

Why don't I see legitimate advocacy as education? It is because, as I will argue in the above section, "What is student?", education requires a student's evaluative stance toward learning they involve. Without the student's freedom of such an evaluation, education is impossible, reducing education to learnification. Advocacy, even legitimate advocacy, is not open for such freedom exactly because student's free evaluation of advocacy may lead to consequences contrary to or different from the aim of the advocacy, including advocacy for safety and survival.

\section{Foisted education for awakening}

Argument: A student's consciousness is often "put asleep" by the forces of oppressive societal hegemony, consumerism, institutional conformity, "false consciousness, " uncritical socialization in a culture, bigotry, self-interest, fears, colonization by an ideology, past traumas, disabling and hopeless circumstances, daily concerns about survival, and so on (cf. Freire, 1986). Left to their own devices, such a student would never be involved in either genuine education, based on evaluation of their own learning and personal transformation, or self-actualization, in which this genuine education is rooted. Strong, forceful, if not even violent, push must be needed by foisted education to awake the student's selfactualization, criticality, authorial agency, and creativity from this lethargic condition of the soul imposed by the society, oppressors, circumstances, and/or the student themselves.

I agree with the argument's basic observation that human consciousness can be, if not always, "colonized" by the given culture, our biology, circumstances, conditions, ideology, and so on. People often uncritically accepted communal and societal values and their own biases. Even more, many of these values and norms are invisible to us. In my view, this condition is both universal and partial. It is universally spread across all people. And it has its own benefits of not overwhelming the human consciousness by constant evaluation of every action, every behavior, every pattern, every desire, every goal, every value. It is also partial because unless severely depressed, which requires medical attention, all people have particular and limited areas of criticality, creativity, authorial agency, and self-actualization. We all are in part asleep and in part awake. In other words, the totalization of the "asleep" human condition, presented in the argument for education for awakening, is wrong.

I also agree that sometimes unpleasant, forced, painful, and even violent experiences can lead to the awakening of the human spirit and can be viewed as educational by the student. For example, in research with my colleagues, we interviewed a young female adult, whom we named Alma, who told us about her horse-riding accident that made her paralyzed and bedridden for more than a year. For this young woman, that life-changing experience was deeply educational as she valued it so highly that she refused to imagine a hypothetical scenario of having her life without this accident while having "the same personal 


\section{A student's right to freedom of education and a teacher's fiduciary obligation to support it}

transformations" (Matusov, Baker, Fan, Choi, \& Hampel, 2017). Probably, even more extreme cases of foisted education for awakening are the stories of some Holocaust survivors who reported about their educational experiences in Nazi concentration camps. Bruno Bettelheim's lessons about saving one's own dignity in inhumane conditions are among the most dramatic (Bettelheim, 1960). It is not by chance that many totalitarian regimes view their concentration camps as "re-education" (Kotek \& Rigoulot, 2000), including the Chinese authorities' recent imprisonment of the Muslim Uyghur minority 9 .

The theme of foisted education for awakening has been explored in the fictional literature after WWII. Thus, in the Hungarian novel "The fifth seal" (Sánta, 1986), a character, named the photographer, reports four friends, he encountered by chance, to the Hungarian Gestapo-like secret police at the end of 1944, during the Arrow Cross Terror, to awaken their consciousness through suffering and facing the existential and moral dilemmas of betrayal and death. In contrast to the totalitarian "re-education" camps seeking the political conformity and the loyalty to the regime, the photographer calls for "real awakening" in those four simpletons, philistines with the asleep souls, - this is how he sees those four friends he encountered. He wants them to stop preoccupying with mundane issues of their everyday life and instead to start contemplating about human destiny and self-sacrifice for higher ideals, at least, once in a while. The photographer seems to accept the notion of personal self-actualization as a goal of education. Finally, the photographer was successful: arguably, all four friends passed the final exam of human dignity and moral virtue, although three of them were killed in the process by the Hungarian Arrow Cross secret state police. Again, in my view, foisted education for awakening is the Enlightenment running amok.

What is wrong with the foisted education for awakening? Aside from the moral issues of sending people to physical and psychological pains, testing people's morality and dignity, and sending them to secret police's brutal interrogation, imprisonment, and death, the foisted education for awakening has its own educational problems. It robs a student from, at least, three important educational aspects: deciding if the student needs this particular awakening, what are limits of this awakening, and how this awakening has to be done. Student's awakening can be legitimately undesirable when it can disrupt the smooth flow of the important unconscious and subconscious processes (so-called "the centipede's dilemma" or Humphrey's $\left.\operatorname{law}^{10}\right)$. Self-awareness can create negative, distracting learning. Even when awakening is desirable for a student, it might have important limits. For example, social relationships are based on trust $-\mathrm{a}$ belief in the benevolence of the actions by other people. A student's attempt to test this belief without limits may lead to a breakdown of the social relationship. Finally, not every means of awakening can be acceptable by the student. Not every student would agree to be paralyzed and bedridden for a year to experience a cathartic educational transformation, Alma did. Exploring one's own limits can be educational experiences in themselves.

Yet, was not Alma, from the example above, foisted by the tragic circumstances of the horse-riding accident, resulting in becoming paralyzed and bedridden for a year, also robbed from these educational aspects? At the same time, she highly valued her transformative personal experiences, foisted by the tragic circumstances, as educational. Why is it the difference between education foisted by blind circumstances versus education foisted by people, carefully designing the student's experiences? The result can be the same: the strong awakening of the student's human spirit.

I argue against education for awakening both foisted by blind circumstances and foisted by people armed with careful pedagogical design because both types of foisted education rob students from important decision making and evaluation, constituting important aspects of education, as I mentioned above.

\footnotetext{
${ }^{9}$ https://www.bbc.com/news/world-asia-china-22278037

${ }^{10}$ https://en.wikipedia.org/wiki/The Centipede\%27s Dilemma
} 


\section{A student's right to freedom of education and a teacher's fiduciary obligation to support it}

Eugene Matusov

However, I think that education for awakening foisted by people is worse than when it is foisted by blind circumstances. It has a different meaning. The former does not have any moral responsibility while the latter does. Done by another human being, the intentional violation of human dignity adds insult to injury.

I think education for awakening can be a powerful and legitimate form of education when freely embarked and designed by the student or consented or trusted by the student to design by a teacher. Foisted education for awakening suppresses important educational aspects and brings the issue of its moral illegitimacy.

\section{Conclusions: Why education needs a student's freedom}

Finally, I want to summarize the reasons why education needs a student's freedom that I tried to articulate in two of my papers in this special issue:

1. For learning or transformative experience to become education, it should involve a student's free authorial judgment, evaluating this experience.

2. A student's evaluation of their own education - what is good for the student to study, how, when, with whom, when to stop education and prioritize something else - is an important part of education itself.

3. Studying on-demand what puzzles, concerns, excites, interests, needs, and bothers the student hereand-now is more consequential for the student's authorial agency - the student's creativity, critical thinking, self-actualization - in the future than forcing the student to study academic subjects preset by the authority because of their expected importance for the future.

4. Education is deeper for the student - more critical, more meaningful, more accurate - when it is rooted in the students' desires.

5. A student's freedom of education makes the student more educationally active, initiative, passionate, and responsible than foisted education.

6. A student's freedom of education recognized by the society and the teacher reduces a need for pedagogical violence so prevalent in foisted education (Matusov \& Sullivan, 2020).

All my claims are empirical (i.e., hypotheses to test), philosophical (i.e., values to examine), and moral (i.e., goodness to question). The empirical investigations help to establish if the listed claims are true or not: whether they exist in the given reality. For example, in our Magic Learning Pill research, my colleagues and I empirically tested Claim\#1. We asked our research participants form three different countries, of different ages and educational experiences to list their past learning experiences for which they would or would not take Magic Learning Pill - an imaginary pill that immediately and effortfully produces the same "learning outcomes" in people as their past learning experiences. In a way, we asked our research participants what kind of past learning they want to shorten and why. To test Claim\#1, we asked two blind coders to predict the research participants' judgments by reading the descriptions of their past learning experiences. The two coders failed - there was a very low and statistically insignificant correlation between their prediction and the participants' judgment of whether they would take the Magic Learning Pill for their past learning experience (Matusov, et al., 2017, pp. 466-467). Thus, our findings have empirically supported Claim\#1, "We therefore conclude that participants' attitude to learning is not grounded in the nature of experiences but in the participants' own authorial evaluative judgment of them" (p. 466). I do not see a problem to turn the rest of the claim into empirical hypotheses for future empirical testing.

The philosophical investigations help us critically examine the desirability of the values behind the listed claims. Do we want to live in society, in which a student's right to freedom of education is recognized and promoted? Can we afford such society now, at some point in the future, or at all? At what expense, this right and described education is established? What and when other important values must be subordinated to a student's right to freedom of education? What are the legitimate limitations of this right? 


\section{A student's right to freedom of education and a teacher's fiduciary obligation to support it}

Eugene Matusov

Finally, the moral analyses question the goodness of the envisioned education. Is the personal education of each student that does not guarantee any public good has to be supported by the public? Is the pursuit of such personal education an important human right? Should people scarify a part of the fruits of their labor to ensure this right of each student to freedom of education for all?

\section{References}

Bakhtin, M. M. (1991). The dialogic imagination: Four essays by M. M. Bakhtin (C. Emerson \& M. Holquist, Trans.). Austin, TX: University of Texas Press.

Bettelheim, B. (1960). The informed heart: Autonomy in a mass age. Glencoe, IL: Free Press.

Biesta, G. (2010). Good education in an age of measurement: Ethics, politics, democracy. Boulder, CO: Paradigm Publishers.

Biesta, G. (2015). What is education for? On good education, teacher judgement, and educational professionalism. European Journal of education, 50(1), 75-87.

Collins, A., \& Halverson, R. (2009). Rethinking education in the age of technology: The digital revolution and schooling in America. New York: Teachers College Press.

DiAngelo, R. J. (2018). White fragility: Why it's so hard for white people to talk about racism(pp. 1 online resource).

Freire, P. (1986). Pedagogy of the oppressed. New York: Continuum.

Greenberg, D. (1991). Free at last: The Sudbury Valley School. Framingham, MA: Sudbury Valley School Press.

Kotek, J., \& Rigoulot, P. (2000). Le siècle des camps: Détention, concentration, extermination, cent ans de mal radical [The century of the camps: Detention, concentration, extermination, one hundred years of radical evil]. Paris: Lattès.

Lave, J. (1992, April). Learning as participation in communities of practice. Presented at the meeting of the American Educational Research Association. Retrieved from http://www.udel.edu/educ/whitson/897s05/files/Lave92.htm

Matusov, E. (2011). Authorial teaching and learning. In E. J. White \& M. Peters (Eds.), Bakhtinian pedagogy: Opportunities and challenges for research, policy and practice in education across the globe (pp. 21-46). New York: Peter Lang Publishers.

Matusov, E. (2020a). Envisioning education in a post-work leisure-based society: A dialogic perspective. New York: Palgrave.

Matusov, E. (2020b). Pattern-recognition, intersubjectivity, and dialogic meaning-making in education (Editorial). Dialogic Pedagogy: An International Online Journal, 8, E1-E24. doi:10.5195/dpj.2020.314

Matusov, E., Baker, D., Fan, Y., Choi, H. J., \& Hampel, R. L. (2017). Magic Learning Pill: Ontological and instrumental learning in order to speed up education. Integrative Psychological and Behavioral Science, 51(3), 456-476. doi:10.1007/s12124-017-9384-8

Matusov, E., \& Sullivan, P. (2020). Pedagogical violence. Integrative Psychological and Behavioral Science, 54(2), 438-464. doi:10.1007/s12124-019-09512-4

McLaren, P. (1993). Schooling as a ritual performance: Towards a political economy of educational symbols and gestures (2nd ed.). London; New York: Routledge.

Neill, A. S. (1960). Summerhill: A radical approach to child rearing. New York: Hart Publishing Company.

Rietmulder, J. (2019). When kids rule the school: The power and promise of democratic education. Gabriola Island, Canada: New Society Publishers.

Rostotsky, S., \& Polonsky, G. (1968). Доживем до понедельника [We'll live till Monday] [Movie]. Moscow: Gorky Film Studios.

Sánta, F. (1986). The fifth seal: A novel (A. Tezla, Trans.). Budapest: Corvina. 


\section{(cc) EY}

New articles in this journal are licensed under a Creative Commons Attribution 4.0 United States License.
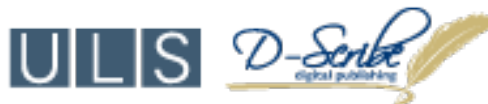

This journal is published by the University Library System, University of Pittsburgh as part of its D-Scribe Digital Publishing Program and is cosponsored by the University of Pittsburgh Press. 